\title{
PEMANFAATAN STYROFOAM SEBAGAI PENGGANTI SEBAGIAN AGREGAT HALUS BETON FAS 0.4
}

\author{
Danindra Pramudya Wardana ${ }^{1}$, Gilang Fadhlurrahman Evriantama², Muhtarom \\ Riyadi $\mathbf{x}^{3}$ \\ 1,2,3 Jurusan Teknik Sipil, Politeknik Negeri Jakarta, Jl. Prof. DR. G.A. Siwabessy, Kukusan, Kecamatan \\ Beji, Kota Depok, Jawa Barat 16424 \\ e-mail: pramudya.danindra@gmail.com,gilang.fe121@gmail.com,muhtard37@gmail.com凶
}

\begin{abstract}
Concrete is a material commonly used for structural work. However, concrete has one disadvantage, namely that its specific gravity is high enough so that the dead load on a structure becomes large. One way to deal with high concrete density is to use Styrofoam waste as a substitute for some of the fine aggregate. This research was conducted to examine the physical and mechanical properties as well as the optimum value of compressive strength, split tensile strength and modulus of elasticity of concrete with a 0.4 fas using Styrofoam as a partial substitute for fine aggregate. The research method used is an experimental method by making the test object in the form of a concrete cylinder with a diameter of 15 $\mathrm{cm}$ and a height of $30 \mathrm{~cm}$. The composition of the concrete mixture used is a volume ratio of 1 Pc: 2 Ps: $2 \mathrm{Kr}$ with a fas 0.4 . The styrofoam variations used are $10 \%, 20 \%$, and $30 \%$ of the ratio to the volume of fine aggregate in normal concrete mixtures. Testing of the mechanical properties of concrete was carried out at the age of $7,14,21$, and 28 days for the concrete compressive strength test, and 28 days for the split tensile strength of the concrete, and the modulus of elasticity. The results showed that the compressive strength of the concrete increased with the age of the concrete and the addition of the styrofoam variations with the exception of the $10 \%$ variation. For the split tensile strength test, there was an increase in line with the increase in the styrofoam variation, while the modulus of elasticity decreased at $10 \%$ variation against $0 \%$ variation and increased at $20 \%$ and $30 \%$ variation with $0 \%$ variation.
\end{abstract}

Keywords: Concrete, Styrofoam, Variation

\begin{abstract}
ABSTRAK
Beton merupakan material yang umum digunakan untuk pekerjaan struktur. Namun beton memiliki salah satu kelemahan yaitu berat jenisnya cukup tinggi sehingga beban mati pada suatu struktur menjadi besar. Salah satu cara menangani berat jenis beton yang tinggi adalah dengan menggunakan limbah styrofoam sebagai pengganti sebagian agregat halus. Penelitian ini dilakukan untuk meneliti sifat fisik dan sifat mekanik serta nilai optimum kuat tekan, kuat tarik belah dan modulus elastisitas dari beton dengan fas 0,4 dengan pemanfaatan Styrofoam sebagai pengganti sebagian agregat halus. Metode penelitian yang digunakan adalah metode eksperimen dengan membuat benda uji berupa silinder beton dengan ukuran diameter $15 \mathrm{~cm}$ dan tinggi $30 \mathrm{~cm}$. Komposisi campuran beton yang digunakan adalah dengan perbandingan volume $1 \mathrm{Pc}: 2 \mathrm{Ps}: 2 \mathrm{Kr}$ dengan fas 0,4. Variasi styrofoam yang digunakan adalah 10\%, 20\%, dan $30 \%$ dari perbandingan terhadap volume agregat halus pada campuran beton normal. Pengujian sifat mekanik beton dilakukan pada umur 7, 14, 21, dan 28 hari untuk uji kuat tekan beton, dan 28 hari untuk kuat tarik belah beton, serta modulus elastisitas. Hasil penelitian menunjukan bahwa kuat tekan beton meningkat seiring dengan bertambahnya umur beton dan penambahan variasi styrofoam terkecuali variasi 10\%. Untuk pengujian kuat tarik belah mengalami peningkatan seiring bertambahnya variasi styrofoam, sedangkan modulus elastisitas mengalami penurunan pada variasi $10 \%$ terhadap variasi $0 \%$ dan mengalami peningkatan pada variasi $20 \%$ dan $30 \%$ terhadap variasi $0 \%$.
\end{abstract}

Kata kunci: Beton, Styrofoam, Variasi 


\section{PENDAHULUAN}

Penggunaan beton sebagai bahan bangunan sudah lama diterapkan secara luas oleh masyarakat sebab memiliki keunggulan yaitu kekuatan yang baik, tahan terhadap api, tahan terhadap perubahan cuaca, serta relatif mudah dalam pengerjaan. Namun beton juga memiliki kelemahan, salah satu kelemahannya adalah berat jenisnya cukup tinggi yaitu $2400 \mathrm{~kg} / \mathrm{m}^{3}$, sehingga beban mati pada suatu struktur menjadi besar. Oleh sebab itu, teknologi beton selalu dituntut berinovasi guna menjawab tantangan akan kebutuhan, diantaranya bersifat ramah lingkungan dan memiliki berat jenis yang rendah (beton ringan). Beton ringan pada umumnya memiliki berat jenis kurang dari $1900 \mathrm{~kg} / \mathrm{m}^{3}$.

Salah satu bahan alternatif yang dapat digunakan adalah limbah Styrofoam karena merupakan salah satu bahan material yang memiliki berat jenis yang rendah. Dengan digunakannya Styrofoam sebagai bahan pengganti agregat halus, maka berat beton akan lebih ringan, serta nilai guna Styrofoam akan bertambah. Namun hal ini akan berpengaruh pada kekuatan beton tersebut.

Tujuan dari penelitian ini adalah untuk mendapatkan sifat fisik dan mekanik beton dan kadar optimum persentase styrofoam sebagai bahan pengganti sebagian agregat halus pada campuran beton.

\section{Beton Styrofoam}

Beton styrofoam adalah jenis beton ringan dengan bahan penyusunnya berupa semen, agregat kasar dan styrofoam serta mempunyai berat jenis sekitar $600 \mathrm{~kg} / \mathrm{m}^{3}$.

Styrofoam digunakan sebagai salah satu bahan pengganti agregat halus untuk beton. Styrofoam merupakan hasil pengolahan dari polysterene. Polysterene merupakan bahan termoplastik hasil dari pengolahan minyak mentah. Secara kimia polysterene ditulis sebagai $\mathrm{CH} 2 \mathrm{CH}(\mathrm{C} 6 \mathrm{H} 5)$-. Polysterene memiliki sifat transparan, lembut, elastis, dengan nilai susutan kecil, mudah diwarnai, dan mudah dibentuk. Polysterene merupakan bahan yang baik ditinjau dari segi mekanis maupun suhu, namun bersifat agak rapuh dan lunak pada suhu dibawah $100^{\circ} \mathrm{C}$ (Billmeyer, 1984). Polysterene memiliki berat jenis sampai $1050 \mathrm{~kg} / \mathrm{m}^{3}$, kuat tarik sampai $40 \mathrm{MN} / \mathrm{m}^{2}$, modulus lentur sampai $3 \mathrm{GN} / \mathrm{m}^{2}$, angka poisson 0,33 (Crawford, 1998)

\section{Kuat Tekan Beton}

Mutu dari sebuah struktur diidentifikasikan dari kuat tekan betonnya. Semakin tinggi tingkat kekuatan struktur, semakin tinggi pula mutu betonnya. Beton harus dirancang proporsi campurannya agar menghasilkan suatu kekuatan rata-rata yang disayaratkan (Juli Ardita Pribadi R dan Marhadi Sastra, 2018). Kuat tekan beton dapat dihitung dengan rumus:

$$
\text { Kuat Tekan }(\sigma \mathrm{t})=\frac{\mathrm{P}}{\mathrm{A}}
$$

Keterangan:

$\sigma_{\mathrm{t}}=$ Kuat tekan beton $\left(\mathrm{Kg} / \mathrm{cm}^{2}\right.$ atau $\mathrm{N} / \mathrm{mm}^{2}$ )

$\mathrm{P}=$ Beban maksimum $(\mathrm{Kg}$ atau $\mathrm{N})$

$\mathrm{A}=$ Luas penampang benda uji ( $\mathrm{cm}^{2}$ atau $\left.\mathrm{mm} 2\right)$

\section{Kuat Tarik Belah Beton}

Berdasarkan SNI 03-2847-2002 besarnya kuat tarik beton adalah 0.33 $\sqrt{f^{\prime} c}$. Kuat tarik belah beton merupakan nilai kuat tarik tidak langsung dari benda uji beton berbentuk silinder yang diperoleh dari beban tekan yang diterapkan secara merata di seluruh panjang dari silinder dimana tumpuannya diletakkan pada bagian 
dasar. Kuat Tarik beton dapat tercapai jika silinder terbelah menjadi dua dari ujung ke ujung. Nilai kuat tarik belah beton dapat dihitung dengan rumus:

$$
\text { Kuat Tarik }(\sigma \mathrm{tr})=\frac{2 P}{\pi D L}
$$

Keterangan:

$\sigma \operatorname{tr}=$ Kuat tarik belah beton $\left(\mathrm{kg} / \mathrm{cm}^{2}\right.$ atau $\left.\mathrm{N} / \mathrm{mm}^{2}\right)$

$\mathrm{P}=$ Beban maksimum $(\mathrm{kg}$ atau $\mathrm{N})$

$\mathrm{L} \quad=$ Panjang benda uji ( $\mathrm{cm}$ atau $\mathrm{mm})$

$\mathrm{D}=$ Diameter benda uji $(\mathrm{cm}$ atau $\mathrm{mm}$ )

\section{Modulus Elastisitas Beton}

Modulus Elastisitas merupakan perbandingan antara besarnya tegangan pada satu satuan regangan. Modulus elastisitas beton tidak pasti dan nilainya tergantung pada kekuatan beton, umur beton, jenis pembebanan, dan karakteristik serta perbandingan antara semen dan agregat.

Rumus menghitung modulus elastisitas eksperimen (ASTM C 46902), yaitu:

$$
\mathrm{Ec}=\frac{(\mathrm{S} 2-\mathrm{S} 1)}{(\varepsilon 2-0,000050)}
$$

Dimana:

$\mathrm{Ec}=$ Modulus Elastisitas Beton $(\mathrm{MPa})$

$\mathrm{S} 1=$ Tegangan pada regangan

$\mathrm{S} 1=0.000050(\mathrm{MPa})$

$\mathrm{S} 2=40 \%$ tegangan $\max (\mathrm{MPa})$

$\varepsilon 2=$ Regangan longitudinal pada saat tegangan S2

Sedangkan secara teoritis, modulus elastisitas beton (Ec) dapat dihitung dengan rumus (SNI 03-2847-2002):

$$
\mathrm{Ec}=0,043 \sqrt{f^{\prime} c} \cdot\left(W c^{1,5}\right)
$$

Dimana:

$\mathrm{Ec}=$ Modulus Elastisitas Beton(MPa)

$\mathrm{f}^{\prime} \mathrm{c}=$ Kuat tekan beton umur 28 hari (MPa)

$\mathrm{Wc}=$ Berat satuan beton $(\mathrm{kg} / \mathrm{m} 3)$

\section{METODE PENELITIAN}

\section{Bagan Alir Penelitian}

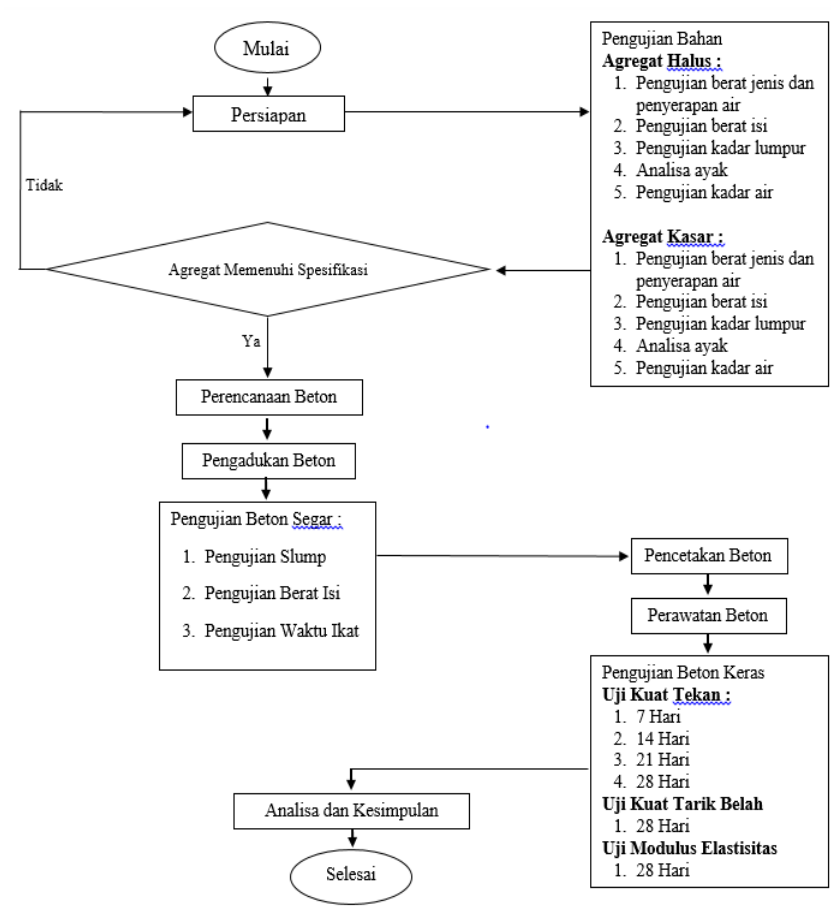

Gambar 1. Bagan Alir Penelitian

\section{Bahan}

Bahan yang digunakan pada penelitian ini yaitu semen (tipe 1 PCC), agregat kasar (batu pecah), agregat halus (pasir alam dan Styrofoam) dan air. Styrofoam yang akan digunakan diparut menggunakan parutan berdiameter $2 \mathrm{~mm}$ sehingga bentuknya menyerupai seperti pasir, kemudian dilakukan pengujian material yang sama dengan pasir.

\section{Pengujian Material}

Setelah semua bahan yang dibutuhkan telah disiapkan, kemudian dilakukan pengujian material. Material yang digunakan yaitu agregat kasar (batu pecah), agregat halus (pasir alam dan Styrofoam). Adapun jenis pemeriksaan yang dilakukan sebagai berikut:

1. Berat jenis dan penyerapan air

2. Berat isi

3. Analisa ayak

4. Kadar lumpur

5. Kadar air 


\section{Rancang Campuran}

Rancang campuran yang digunakan dalam penelitian ini adalah menggunakan metode perbandingan berat dengan perbandingan 1:2:2 (semen : ag. halus : ag. kasar). Berikut adalah proporsi campuran yang didapat dari perbandingan campuran 1:2:2.

$$
\begin{aligned}
& \text { Kebutuhan Bahan } 1 \text { Variasi (15 Benda } \\
& \begin{aligned}
& \text { Uji) } \\
&-\quad \text { PC }=(87.45 / 248.412) \times 100 \\
&=\mathbf{3 6 ~ K g} \\
&-\quad \text { Pasir }=(87.45 / 248.412) \times 200 \\
&=\mathbf{7 2 ~} \mathbf{~ K g} \\
&-\quad \text { Kerikil }=(87.45 / 248.412) \times 200 \\
&=\mathbf{7 2 ~} \mathbf{~ K g} \\
&-\quad \text { Air }=(87.45 / 248.412) \times 40 \\
&=\mathbf{1 4 . 4} \mathbf{~ K g}
\end{aligned}
\end{aligned}
$$

\begin{tabular}{|c|c|}
\hline $\begin{array}{c}\text { Volume Styrofoam yang diperlukan } \\
\text { (liter) }\end{array}$ & $\begin{array}{c}\text { Pasir yang diperlukan } \\
\text { (Kg) }\end{array}$ \\
\hline $10 \%=\frac{7.2 \mathrm{Kg}}{1.05 \mathrm{Kg} / \text { /iter }}=6.857$ liter & $90 \% \times 72 \mathrm{Kg}=64.8 \mathrm{Kg}$ \\
\hline $20 \%=\frac{14.4 \mathrm{Kg}}{1.05 \mathrm{Kg} / \text { liter }}=13.714$ liter & $80 \% \times 72 \mathrm{Kg}=57.6 \mathrm{Kg}$ \\
\hline $30 \%=\frac{21.6 \mathrm{Kg}}{1.05 \mathrm{Kg} / \text { iter }}=20.571$ liter & $70 \% \times 72 \mathrm{Kg}=50.4 \mathrm{Kg}$ \\
\hline
\end{tabular}

Gambar 2. Kebutuhan Bahan

\section{Pembuatan Benda Uji}

Pembuatan benda uji dilakukan di Laboratorium Teknik Sipil Politeknik Negeri Jakarta dengan menggunakan mesin molen. Setiap satu kali pengadukan digunakan untuk membuat 1 variasi dengan jumlah benda uji sebanyak 15 sampel. Benda uji berbentuk silinder dengan ukuran diameter $15 \mathrm{~cm}$ dan tinggi $30 \mathrm{~cm}$ digunakan untuk pengujian kuat tekan, kuat tarik dan modulus elastisitas. Setelah diaduk, beton segar dimasukkan ke dalam cetakan kemudian buka cetakan setelah kurang lebih 24 jam. Setelah dilepas dari cetakan, kemudian dilakukan perawatan beton dengan cara direndam.

\section{Pengujian Sifat Mekanik Beton}

Setelah benda uji mencapai umur yang telah ditentukan untuk melakukan pengujian, benda uji diambil dari tempat perendaman dan dikeringkan. Setelah benda uji kering, dilakukan pengujian kuat tekan, kuat tarik, dan modulus elastisitas menggunakan mesin tekan.

\section{HASIL dan PEMBAHASAN}

\section{Workability Beton Segar}

Pengujian Slump dilakukan setelah tahap pengadukan selesai. Pengujian ini dilakukan untuk mengetahui tingkat kemudahan pengerjaan (workability) dari beton.

Dari hasil pengujian, didapatkan nilai slump pada variasi $10 \%$ sebesar $\mathbf{1 7 5}$ mm, pada variasi $20 \%$ sebesar $140 \mathbf{~ m m}$ dan pada variasi $30 \%$ sebesar 110 mm. Dapat disimpulkan bahwa semakin banyak jumlah/presentase styrofoam yang ditambahkan kedalam campuran beton, maka semakin kecil nilai slump yang dihasilkan. Dengan berkurangnya nilai slump, maka workability beton juga mengalami penurunan.

\section{Berat Isi}

Pengujian berat isi dilakukan setelah nilai slump sudah mencapai target yang telah ditentukan. Pengujian ini dilakukan untuk mengetahui perubahan berat isi beton segar setelah digunakannya Styrofoam sebagai pengganti sebagian agregat halus .

Dari hasil pengujian yang telah dilakukan, dapat disimpulkan bahwa semakin banyak jumlah/persentase styrofoam yang dicampurkan kedalam campuran beton maka semakin besar berat isi beton segar yang dihasilkan. 


\section{Waktu Ikat}

Pengujian waktu ikat dilakukan setelah nilai slump sudah mencapai target yang telah ditentukan. Pengujian ini dilakukan untuk mengetahui berapa lama waktu yang dibutuhkan oleh beton untuk mengeras setelah digunakannya Styrofoam sebagai pengganti sebagian agregat halus.

Berdasarkan pengujian waktu ikat, dapat disimpulkan bahwa semakin banyak jumlah/persentase styrofoam yang ditambahkan kedalam campuran beton, maka semakin cepat waktu pengikatannya.

\section{Kuat Tekan}

Pengujian kuat tekan dilakukan pada umur 7 hari, 14 hari, 21 hari dan 28 hari dengan menggunakan benda uji berbentuk silinder berdiameter $15 \mathrm{~cm}$ dan tinggi $30 \mathrm{~cm}$.

Berdasarkan hasil pengujian kuat tekan pada umur 28 hari, dapat disimpulkan bahwa kuat tekan beton mengalami penurunan pada variasi styrofoam $10 \%$ terhadap variasi styrofoam 0 . Kuat tekan pada beton dengan variasi styrofoam $20 \%$ mengalami kenaikan terhadap variasi styrofoam 0\%. Kuat tekan beton tertinggi diperoleh oleh beton dengan variasi styrofoam $30 \%$ dengan nilai kuat tekan beton rata-rata yaitu 15.909 $\mathrm{N} / \mathrm{mm}^{2}$.

\section{Kuat Tarik Belah}

Pengujian kuat tekan dilakukan pada umur 28 hari dengan menggunakan benda uji berbentuk silinder berdiameter $15 \mathrm{~cm}$ dan tinggi $30 \mathrm{~cm}$.

Berdasarkan hasil pengujian kuat tarik belah pada umur 28 hari, dapat disimpulkan bahwa kuat tarik beton mengalami peningkatan pada variasi styrofoam $10 \%, 20 \%$ dan $30 \% \%$ terhadap variasi styrofoam $0 \%$. Kuat tarik belah beton tertinggi diperoleh oleh beton dengan variasi Styrofoam $30 \%$ dengan nilai kuat tarik belah beton ratarata yaitu $1.136 \mathrm{~N} / \mathrm{mm} 2$.

\section{Modulus Elastisitas}

Pengujian modulus elastisitas dilakukan dengan menggunakan benda uji silinder yang sama dengan pengujian kuat tekan pada umur 28 hari.

Dari grafik Modulus Elastisitas dapat disimpulkan bahwa nilai modulus elastisitas eksperimen dan nilai modulus elastisitas teoritis mengalami penurunan pada variasi $10 \%$ terhadap variasi $0 \%$. Sedangkan variasi $20 \%$ dan $30 \%$ mengalami peningkatan terhadap variasi $0 \%$. Modulus elastisitas tertinggi diperoleh oleh beton dengan variasi styrofoam $30 \%$ dengan nilai modulus elastisitas beton rata-rata yaitu $17316.538 \mathrm{~N} / \mathrm{mm} 2$ untuk modulus elastisitas eksperimen dan 14712.99 $\mathrm{N} / \mathrm{mm}^{2}$ untuk modulus elastisitas teoritis.

\section{KESIMPULAN}

\section{Sifat Fisik Beton}

1. Nilai slump beton variasi Styrofoam $10 \%$ mengalami peningkatan.

2. Nilai slump beton variasi Styrofoam $20 \%$ dan $30 \%$ mengalami penurunan.

3. Berat isi beton segar variasi Styrofoam $10 \%$ mengalami penurunan.

4. Berat isi beton segar variasi Styrofoam $20 \%$ dan $30 \%$ mengalami peningkatan. $\mathrm{W}$

5. Waktu ikat awal untuk beton segar variasi Styrofoam 10\% mengalami perlambatan.

6. Waktu ikat awal beton segar variasi Styrofoam $20 \%$ dan $30 \%$ mengalami percepatan.

\section{Sifat Mekanik Beton}

1. Nilai kuat tekan beton pada umur 28 hari mengalami penurunan pada variasi Styrofoam $10 \%$.

2. Nilai kuat tekan beton pada variasi Styrofoam $20 \%$ dan $30 \%$ mengalami peningkatan. 
3. Nilai kuat tarik beton pada umur 28 hari mengalami peningkatan pada variasi Styrofoam 10\%, 20\%, dan 30.

4. Nilai Modulus Elastisitas beton pada umur 28 hari mengalami peningkatan pada variasi Styrofoam $10 \%$.

5. Nilai Modulus Elastisitas beton pada variasi Styrofoam 20\% dan $30 \%$ mengalami penurunan.

\section{Nilai Optimum}

1. Berdasarkan nilai kuat tekan, kuat tarik belah dan modulus elastisitas beton pada umur 28 hari belum diperoleh nilai optimum karena hasil yang terus mengalami peningkatan.

2. Sedangkan persentase Styrofoam yang menghasilkan nilai kuat tekan, kuat tarik belah dan modulus elastisitas yang paling tinggi terhadap variasi Styrofoam 10\%, $20 \%$, dan $30 \%$ yaitu pada beton dengan variasi Styrofoam 30\%.

\section{DAFTAR PUSTAKA}

[1] Giri Sudarsana Agustingingsih, "Kuat Tarik Belah dan Lentur Beton Dengan Penambahan Styrofoam (Styrocom)" Jurnal Teknik Sipil, vol.12, No. 2, 2008.

[2] Sudipta Sudarsana, "Permeabilitas Beton Dengan Penambahan
Styrofoam" Jurnal Teknik Sipil, vol.13, No. 2, 2014.

[3] Tjokrodimulyo, Teknologi Beton Edisi Pertama. Yogyakarta: Teknik Sipil Universitas Gajah Mada, 2007

[4] Yoppi Nadia, "Pengaruh Penggunaan Styrofoam Sebagai Pengganti Agregat Kasar Terhadap Kuat Tekan Beton", Jurnal Konstruksia, vol. 5, No. 2, 2014.

[5] Dharmagiri I.B, dkk, "Kuat Tekan dan Modulus Elastisitas Beton Dengan Penambahan Styrofoam (Styrocon)", Jurnal Ilmiah Teknik Sipil, Vol. 12, No. 1, 2008.

[6] Bilmeyer, JR, FW, Text Book of Polymer Science, Third Edition. SINGAPORE: John Wiley and Sons, Inc, 1984.

[7] Badan Standarisasi Nasional, Tata Cara Pembuatan Rencana Campuran Beton Normal SK SNI 03-2834-2002, Bandung: BSN, 2000.

[8] Badan Standarisasi Nasional, Tata Cara Perencanaan Struktur Beton Untuk Bangunan Gedung dengan Standar SK SNI 03-2487-2002, Bandung: BSN, 2002

[9] ASTM C 469-02

[10] Crawford, R.J., 1998, Plastic Engineering, Third Edition 


\section{Lampiran}

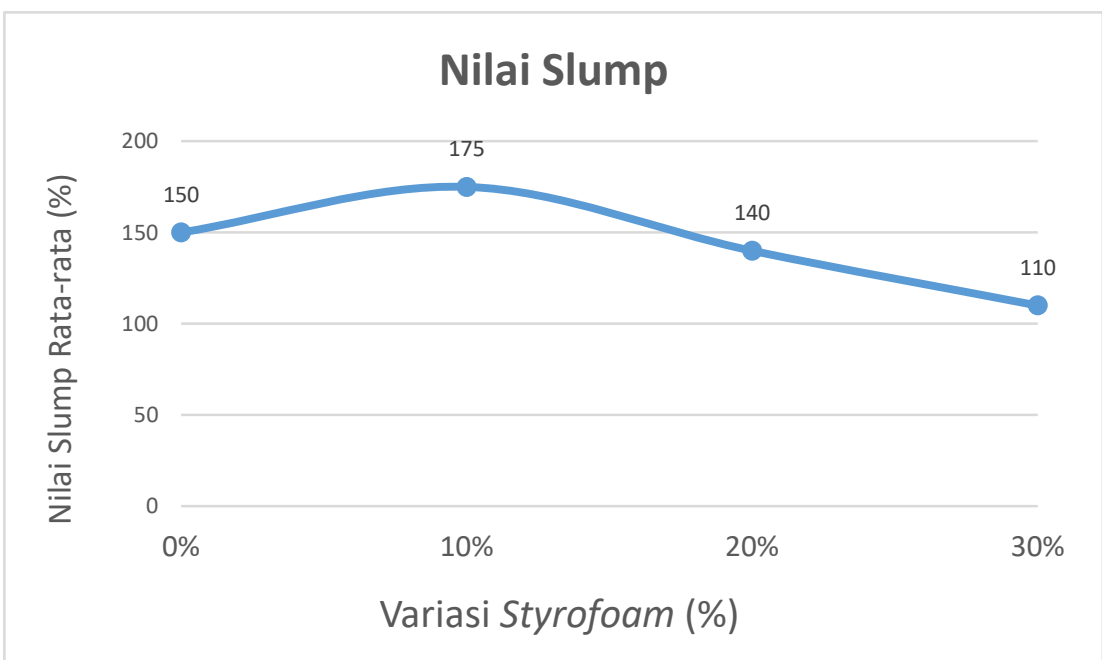

Gambar 3. Grafik Nilai Slump

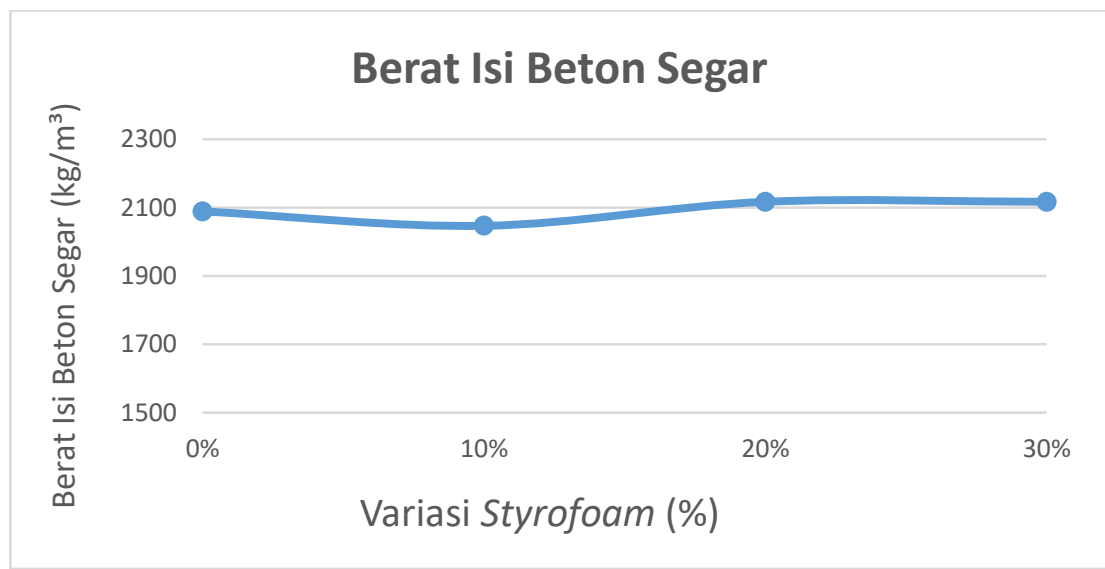

Gambar 4. Grafik Nilai Beton Segar

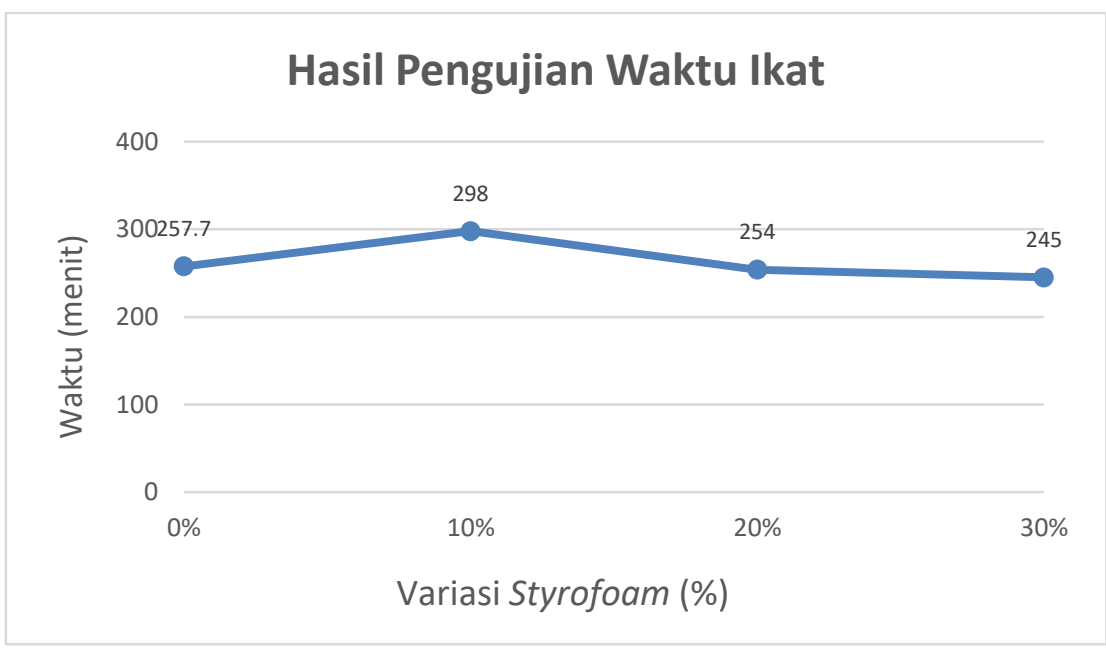

Gambar 5. Grafik Nilai Waktu Ikat 
Danindra, dkk., Pemanfaatan Styrofoam Sebagai...

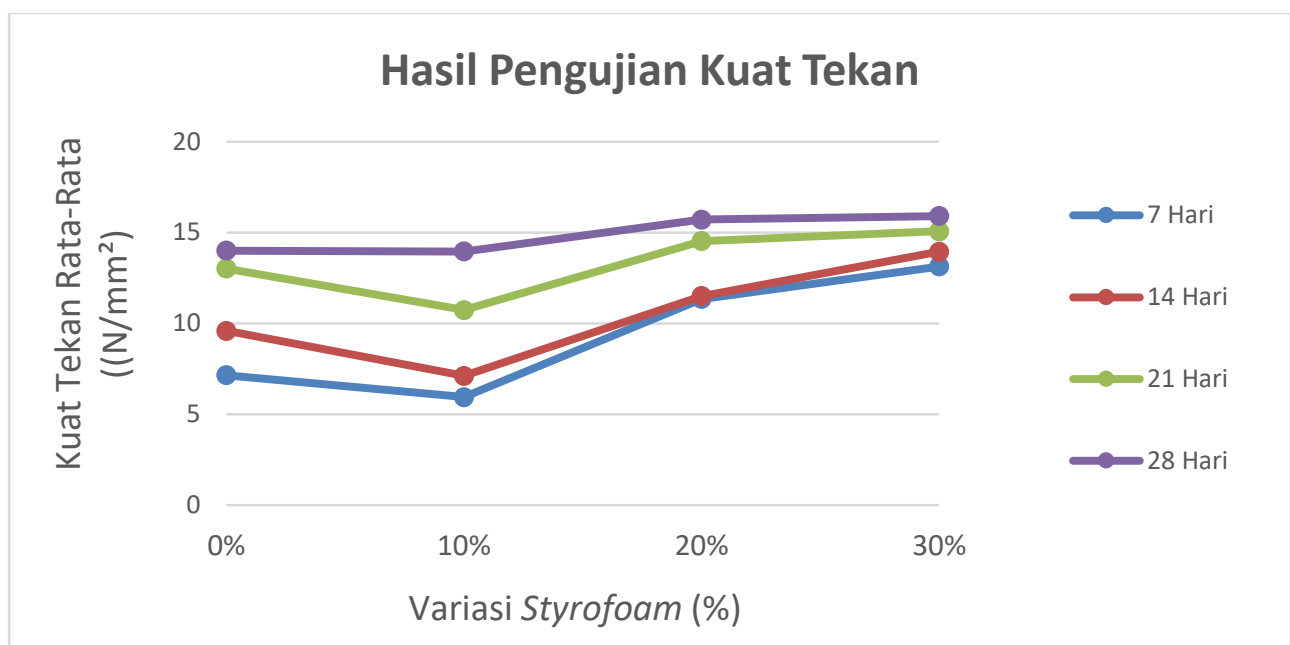

Gambar 6. Grafik Nilai Kuat Tekan

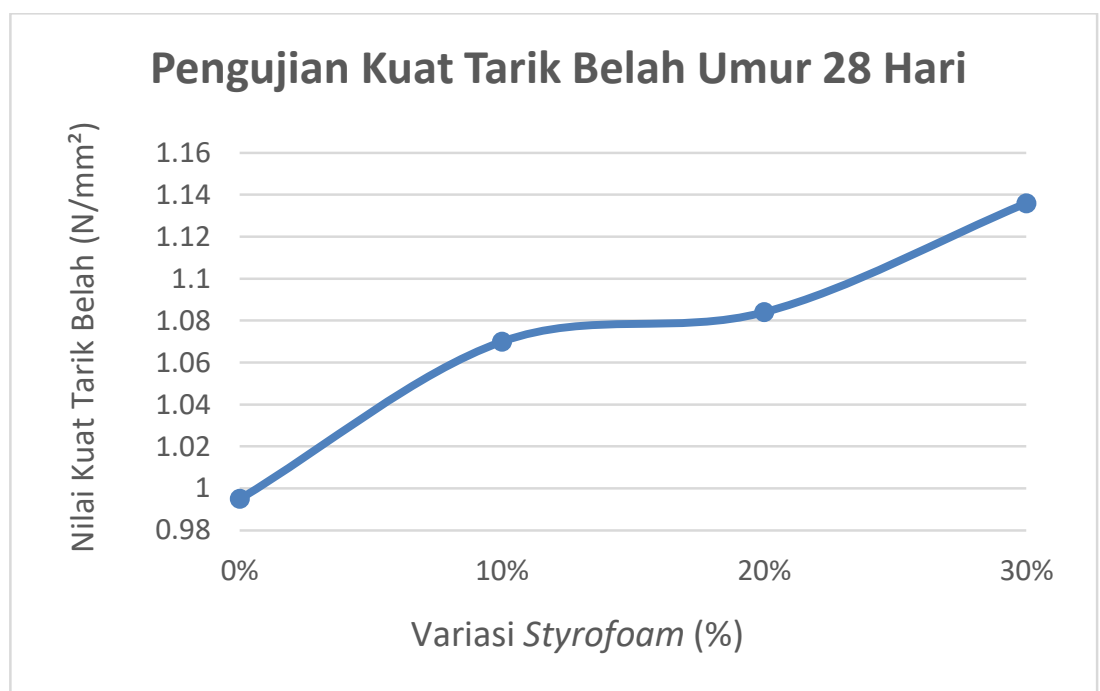

Gambar 7. Grafik Nilai Kuat Tarik Belah

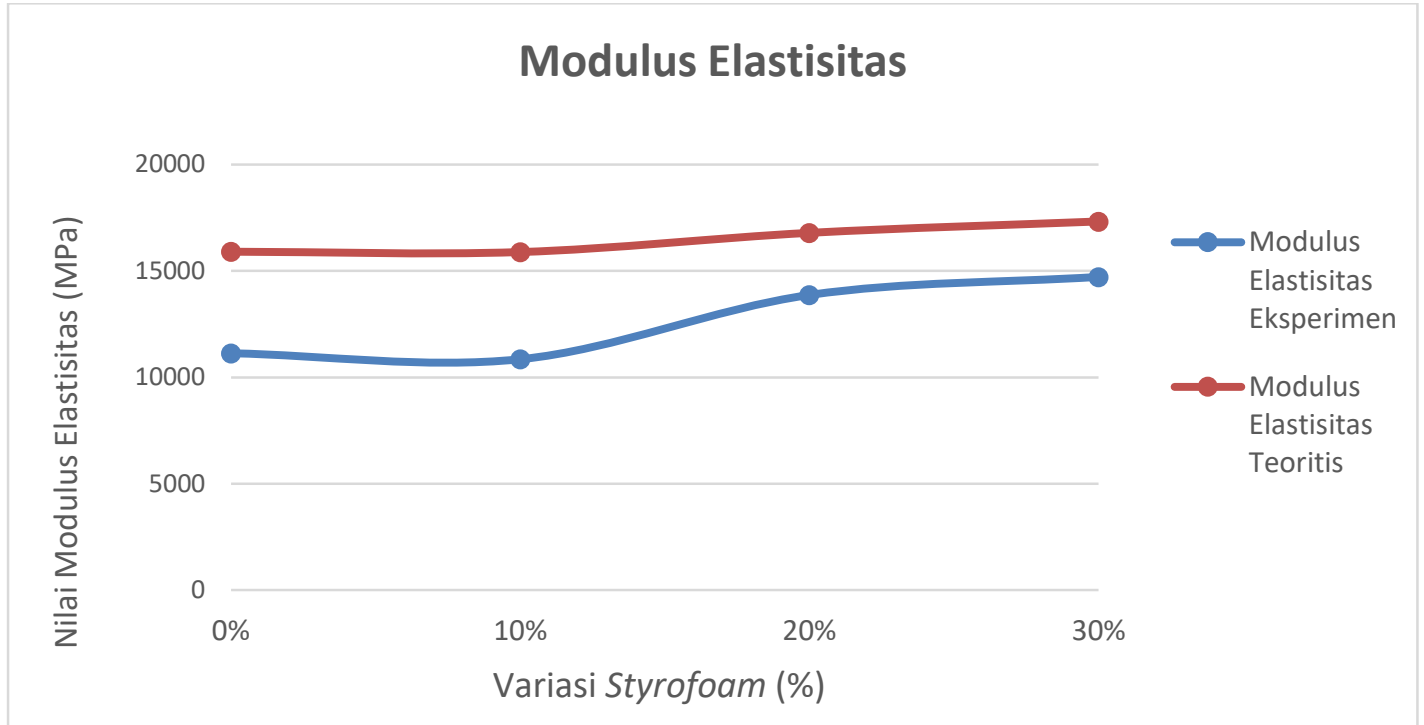

Gambar 8. Grafik Nilai Modulus Elastisitas 